\title{
TWO NEW SPECIES OF PREDATORY MITES ACARINA: PHYTOSEIIDAE FROM KERALA, INDIA
}

\author{
Mary Anithalatha Sadanandan ${ }^{1}$ and N. Ramani ${ }^{2}$ \\ ${ }^{1}$ P.G. \& Research Department of Zoology, Malabar Christian College, Kozhikode, Kerala 673001, India \\ ${ }^{2}$ Department of Zoology, University of Calicut, Kerala, India
}

\begin{abstract}
A survey on the predatory mite fauna of the family Phytoseiidae harbouring on various species of economically important plants in northern Kerala enabled us to locate 40 species under nine genera. Of those, two new species of Amblyseius (Amblyseius) are described here with appropriate illustrations.
\end{abstract}

\author{
KEYWORDS \\ Amblyseius amorphalae $s p$. nov., Amblyseius bhadrakshae \\ sp. nov., Kerala, new species, Phytoseiidae, \\ predatory mites \\ Abbreviations \\ Cf - Chelicera of female; $\mathrm{Cm}$ - Chelicera of male; DF - Dorsal \\ view of female; DM - Dorsal view of male; DZUC - Department \\ of Zoology University of Calcut; LIV -Leg IV showing setation; \\ $\mathrm{Mp}$ - Metapodal plate; Sp - spermatheca; VF - Ventral view of \\ female; VM - Ventral view of male.
}

Predatory mites of the family Phytoseiidae are recognized as one of the most valuable groups of predators on plant feeding mites, especially spider mites (Quayle, 1912; Ewing, 1914). Mass multiplication methods have been developed to use these predators in commercial scale on a variety of crops (Lo et al., 1979; Krishnamoorthy, 1982). Phytoseiidae contain 168 known species under 12 genera (Gupta \& Gupta, 1999). A systematic survey was undertaken to document new species of Pytoseiidae from various districts of northern Kerala to augment the scanty information available from peninsular India. All the measurements are given in microns. All the type specimens have been deposited in the acarological collections maintained at the Department of Zoology, University of Calicut, Kerala, India. The differences in characteristics from the previously described species justify describing them as new species.

\section{Amblyseius (Amblyseius) amorphalae sp. nov.} (Figure 1)

\section{Material examined}

Holotype: Female marked on the slide along with four other females and a male, 30.ix.2000, Dharmadam, Kannur district, Kerala, India, coll. M.A. Sadanandan (DZUC, No. A 2/7), ex. Amorphophallus companulatus

Paratype: Two slides with 10 females, details same as holotype (DZUC, No. A 2/2, 2/4).

\section{Female}

Dorsal shield 403 long, 278 wide with 17 pairs of setae and two pairs of small pores. Setae $\mathrm{j}_{1}, \mathrm{j}_{3}, \mathrm{~s}_{4}, \mathrm{Z}_{4}, \mathrm{Z}_{5}$ long. Measurements of setae: $j_{1}-33, j_{3}-42, s_{4}-90, z_{4}-90, Z_{5}-225$, all other setae between 6 and $8 ; r_{3}=R_{1}=8$ each, both on lateral integument.
Sternal shield 90 long, 105 wide with three pairs of sternal setae (21), metasternal plate with setae distinct. Genital shield 92 wide with a pair of setae (28). A clear band present between genital and ventrianal shield. Ventrianal shield 120 long, 75 wide, vase shaped with concave lateral margins, three pairs of preanal setae (15) and a pair of semilunar pores. Four pairs of setae present around ventrianal shield; $\mathrm{JV}_{5}-45$ long, smooth. Two pairs of metapodal plates present, primary one 24 and accessory one 16 long. Fixed digit of chelicera with four teeth anterior to pilus dentilis and three teeth posterior to it; movable digit with three teeth. Peritreme extends anteriorly beyond $\mathrm{j}_{1}$. Spermatheca with short cervix and a bulged, rounded capitulum. Macrosetae on Leg IV: genu - 111, tibia - 75, basitarsus - 60 . Leg chaetotaxy :

genu II $2 \frac{2}{0}-\frac{2}{0}-1$, tibia II $1 \frac{1}{1}-\frac{2}{1}-1$; genu III $1 \frac{2}{1}-\frac{2}{0}-1$, tibia III $1 \frac{1}{1}-\frac{2}{1}-1$

\section{Male}

Dorsal chaetotaxy similar to that of female Spermatophoral process, ventrianal shield and sternitigenital shield as illustrated.

\section{Remarks}

The specimen examined resembles $A$. (A.) largoensis (Muma) in the dorsal chaetotaxy, shape of ventrianal shield but can be differentiated from it by the following characters:

1. Spermatheca with short cervix instead of the long one in $A$. (A.) largoensis (Muma).

2. Macrosetae on basitarsus of Leg IV longer in the new species. 3. Movable digit of the chelicera with three teeth instead of two in A. (A.) largoensis (Muma).

\section{Amblyseius (Amblyseius) bhadrakshae sp. nov.}

(Figure 2)

\section{Material studied}

Holotype: Female, 17.iv.2001, Ayurvedic Herbal Garden of Kottakkal Arya Vaidya Sala, Kottakkal, Malappuram district, Kerala, India, coll. M.A. Sadanandan (DZUC, No. A 37/1), ex. Scaevola taccada. Holotype female marked on the slide along with 3 females and a larva.

Paratype: Slide with 6 females, details same as that of holotype (DZUC, No. A 37/2).

\section{Female}

Dorsal shield 372 long, 240 wide with 17 pairs of setae, $\mathrm{j}_{1}, \mathrm{j}_{3}, \mathrm{~s}_{4}$, $Z_{4}$ and $Z_{5}$ long, all others small. Measurements of setae: $j_{1}-36$, $\mathrm{j}_{3}-42, \mathrm{j}_{4}, \mathrm{j}_{6}, \mathrm{j}_{2}, \mathrm{~J}_{5}-5$ each, $\mathrm{z}_{2}-8, \mathrm{z}_{4}-12, \mathrm{z}_{5}-6, \mathrm{~s}_{4}-125, \mathrm{Z}_{1}, 10, \mathrm{~S}_{2}-$ $12, S_{4}-12, S_{5}-11, Z_{4}-108, Z_{5}-225$. Sublateral setae $r_{3}-10, R_{1}$ (C) Zoo Outreach Organisation; www.zoosprint.org Manuscript 1221; Received 23 June 2004; Revised received 14 February 2006; Finally accepted 26 April 2006 ; Date of publication 21 May 2006 June 2006 | ISSN 0973-2535 (Print edition); 0973-2551 (Online edition) 

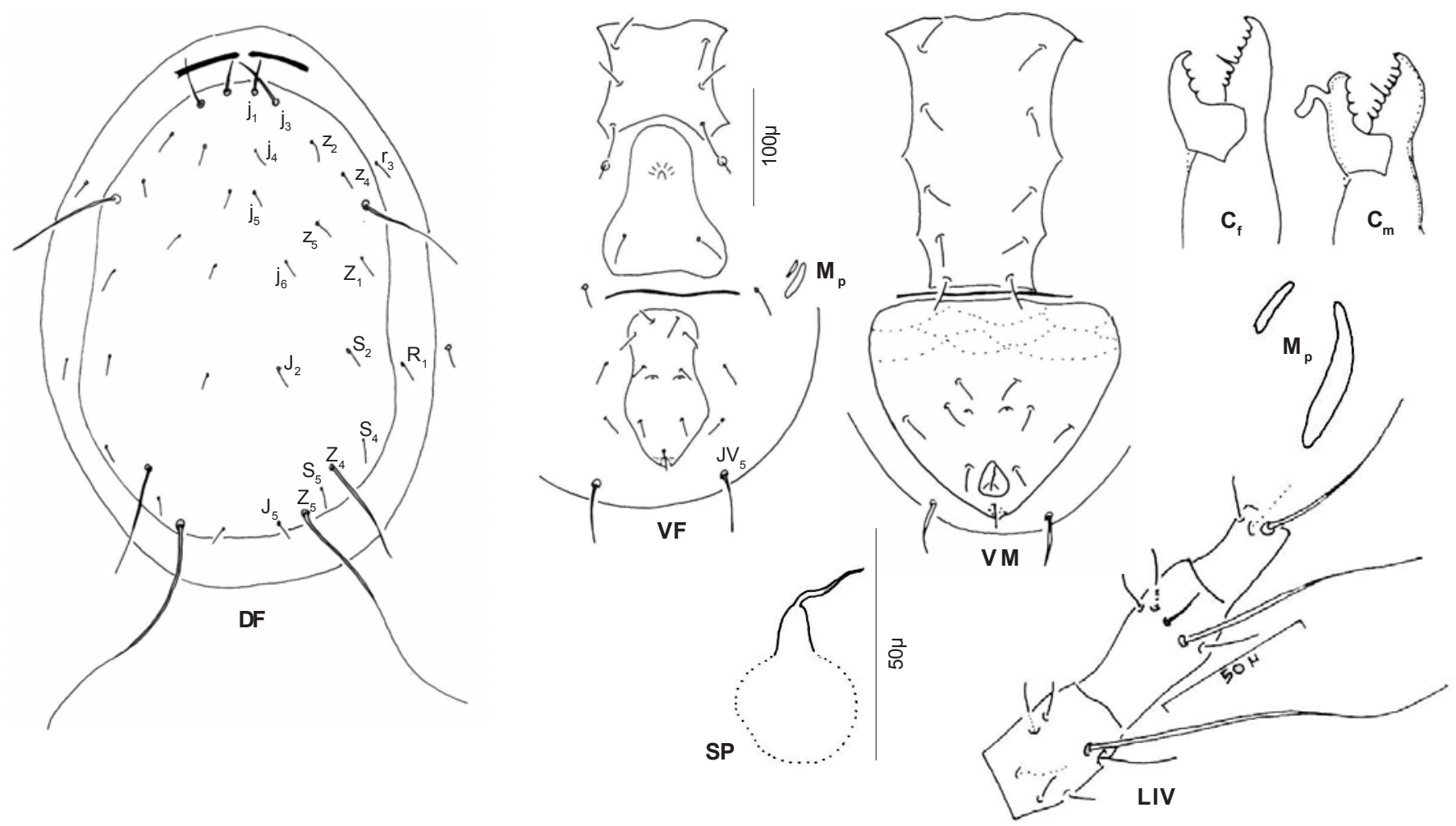

Figure 1. Amblyseius (Amblyseius) amorphalae sp. nov.
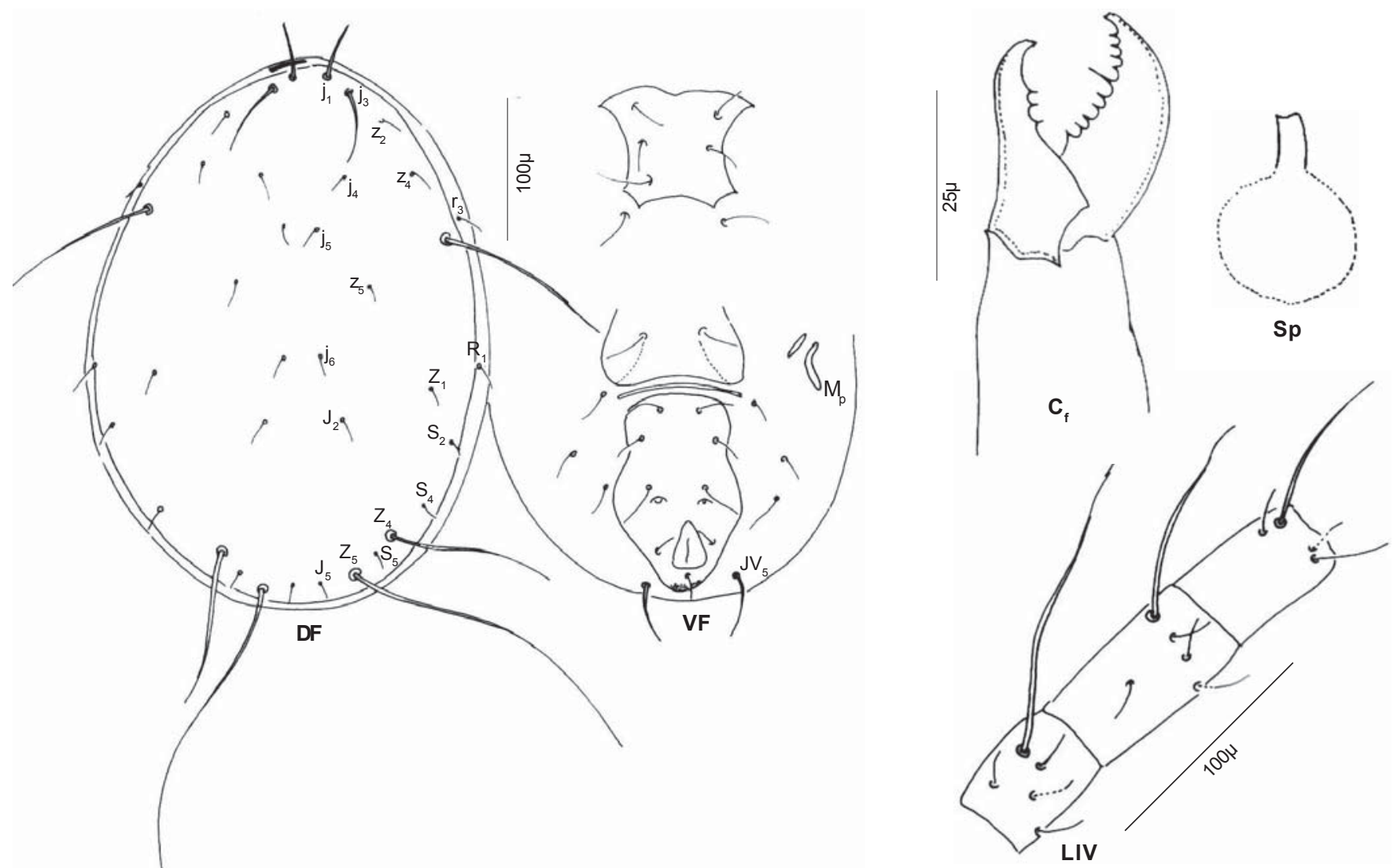

Figure 2. Amblyseius (Amblyseius) bhadrakshae sp. nov. 
- 8, both on the lateral integument. Sternal shield 76 long, 98 wide with three pairs of sternal setae (20 long), metasternal plate with setae distinct. Genital shield 90 wide with a pair of genital setae (24 long). A clear fold seen between genital shield and ventrianal shield. Ventrianal shield 120 long, 75 wide as figured with three pairs of preanal setae, a pair of preanal pores located little below the level of third pair of preanal setae; four pairs of setae present around ventrianal shield; setae $\mathrm{JV}_{5}-60$ long. Two pairs of metapodal plates present, primary one - 20 long, accessory one 12 long. Fixed digit of chelicera with five teeth posterior to pilus dentilis and four teeth anterior to it; movable digit with three teeth. Peritreme extends anterior to $j_{1}$. Spermatheca with short cervix. Macrosetae on Leg IV: genu 128, tibia - 90 and basitarsus - 75 .

Leg Chaetotaxy:

genu II 2 $\frac{2}{0}-\frac{2}{0}-1$, tibia II $1 \frac{1}{1}-\frac{2}{1}-1$; genu III $1 \frac{2}{0}-\frac{2}{1}$, t, tibia III $1 \frac{1}{1}-\frac{2}{1}-1$

Male

Unknown.

\section{Remarks}

This new species resembles A. (A.) herbicolus (Chant) 1959, but differs from it by the following characters:

1. Shape of spermatheca is different from A. (A.) herbicolus (Chant).

2. Fixed digit of chelicera with five teeth posterior to pilus dentilis and four teeth anterior to it, unlike that of $A$. (A.) herbicolus (Chant).

3. Dorsal shield is longer in the new species.

4. Setae $\mathrm{j}_{1}$ is longer (36) instead of 25 in $A$. (A.) herbicolus (Chant).

\section{REFERENCES}

Chant, D.A. (1959). Phytoseiid mites (Acarina: Phytoseiidae). Canadian Journal of Entomology 91(Supp1. 12): 84-85.

Ewing, H.E. (1914). The common red spider or spider mite. Bulletin of the Oregon Agricultural Experimentation Station 121: 95.

Gupta, S.K. (1986). Fauna of India (Acari: Mesostigmata) Family Phytoseiidae. Zoological Survey of India, Calcutta, 350pp.

Gupta, S.K. and A. Gupta (1999). Progress of taxonomic research on Indian mites upto the end of twentieth century and prospects of research in the next millennium. Journal of Acarology 15(1-2): 8-83.

Krishnamoorthy, A. (1982). Mass rearing technique for a indigenous predatory mite Amblyseius tetranychivorous Gupta (Acarina: Phytoseiidae) in the laboratory. Entomon 7: 47-49.

Lo, K.C., C.C. Ho and S.T. Chen (1979). Artificial propagation of Amblyseius taiwanicus and its tolerance to some pesticides. Journal of Agricultural Research China 28: 251-259.

Quayle, H.J. (1912). Red spiders and mites of citrus tree. California Agriculutre Experimentation Station Bulletin 234: 483-530.

\section{ACKNOWledgements}

The authors are thankful to Dr. S.K. Gupta, Emeritus Scientist, Ministry of Environment and Forests, Government of India for confirming the identification of the species included in this paper. The first author is also thankful for the financial support extended under the FIP of the U.G.C., New Delhi. For facilities, we thank the authorities of the University of Calicut.

\section{LENGTH-WEIGHT RELATIONSHIP OF FINFISH OREOCHROMIS MOSSAMBICA (PETERS) FROM JANNAPURA POND, KARNATAKA}

\author{
B.R. Kiran, E.T. Puttaiah, S. Thirumala and \\ A.B. Banakar
}

Department of Environmental Science, Kuvempu University, Shankaraghatta, Karnataka 577451, India

The study of length-weight relationship of fish gives an idea of their growth rates. Generally, when the length increases, the weight also increases correspondingly, showing that the weight of the fish is a function of its length. Establishment of a mathematical equation is useful in determining either the weight or the length of a given fish species from a particular locality. Use of such mathematical equations are very common to fishery biologists.

Considerable literature is available on the length-weigth relationship of different fish species. It has been found by many workers that this relationship usually follows the cube law, i.e., $\mathrm{W}=\mathrm{aL}^{\mathrm{b}}$ (Roy, 1986). However, sometimes, the growth pattern does not strictly agree with the isometric growth formula. The deviations from the hypothetical value of 3 (Ricker, 1958) is either due to environmental factors (Seasonal variations, population dynamics, taxonomic differences etc.) or due to condition of the fish (maturity, spawning etc.). Such deviations have been observed by Sarojini (1957) in Mugil parsia, Lal (1980) in Schizothorax plagiostomus and Lal and Mishra (1980) in Schizothorax richardsonii.

Oreochromis mossambica (of the family Cichlidae) is widely cultivated in ponds, lakes, tanks, pools and rivers in India. Due to its availability throughout the year, it is a popular food item in the Malnad region of Karnataka. This fish is known for its nutritive and therapeutic qualities and its taste.

A perusal of the available literature indicates that information on the morphometric relationship of this fish is lacking in the Malnad region of Karnataka. A total of 70 specimens of Oreochromis mossambica (30 males and 40 females) for this investigation were collected during the period from November 2004 to April 2005 from Jannapura pond $\left(13^{\circ} 45^{\prime} 00^{\prime \prime N} \&\right.$ $75^{\circ} 30^{\prime} 14^{\prime \prime E}$ ), situated $20 \mathrm{~km}$ away from Kuvempu University campus. The pond receives the water from Bhadra reservoir left bank channel and sewage from residential settlements.

Length of the fishes were measured and weighed in fresh condition to the nearest $0.1 \mathrm{~mm}$ and $0.1 \mathrm{~g}$ respectively. The length-weight relationship was estimated using the formula $\mathrm{W}$ $=\mathrm{aL}^{\mathrm{b}}$ (Lecren, 1951; Annappaswamy et al., 2004) where $\mathrm{W}=$ Weight of the fish, $L=$ Length of the fish and ' $a$ ' and ' $b$ ' are constants, or, it can be linearly represented as $\log \mathrm{W}=\log \mathrm{a}+$ b Log L. The constants Log ' $a$ ' and ' $b$ ' in the above equation

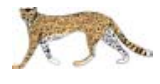

